\title{
ANALISIS PENGARUH TEKNOLOGI INFORMASI PADA IKLIM ORGANISASI DAN DAMPAKNYA TERHADAP KOMITMEN ORGANISASI PERGURUAN TINGGI SWASTA
}

\author{
${ }^{1}$ Galih Abdul Fatah Maulani ${ }^{2}$ Teten Mohamad Sapril Mubarok \\ ${ }^{1}$ galihafm@uniga.ac.id \\ 2teten@uniga.ac.id \\ ${ }^{12}$ Fakultas Kewirausahaan, Universitas Garut \\ Kampus 4 Universitas Garut Jln. Terusan Pahlawan, Tarogong - Garut
}

\begin{abstract}
ABSTRAK
In the Industrial Revolution 4.0 and Society 5.0, the role and position of Information Technology have become very vital for any organization where information technology is a business strategy that can maintain the existence of an organization, including private universities. The purpose of this study was to analyze and determine the effect of information technology on the organizational climate of private universities in Garut Regency and its impact on organizational commitment to the university environment. Besides, this research has an urgency to find out how big the role of information technology in the midst of an organization that has not optimally implemented this technology as a supporting tool in private universities' business processes. The research methodology used is descriptive research and verification. Descriptive research aims to obtain a description or characteristics of a variable, in this case, the information technology variable, higher education organizational climate, and higher education organizational commitment. This study's results reveal that there is a significant influence between information technology on organizational climate in private universities, besides that there is also a significant impact on the commitment made by private universities in Garut Regency.
\end{abstract}

Keywords: Information Technology, Organizational Climate, Organizational Commitmens; Higher Education Institutions.

\begin{abstract}
ABSTRAK
Dalam era Revolusi Industri 4.0 dan Society 5.0 peran dan posisi Teknologi Informasi menjadi sangat vital bagi setiap organisasi dimana teknologi informasi menjadi strategi bisnis yang dapat menjada eksistensi sebuah organisasi, tak terkecuali Perguruan Tinggi Swasta. Tujuan Penelitian ini adalah untuk menganalisis dan mengetahui pengaruh teknologi informasi terhadap iklim organisasi perguruan tinggi swasta di Kabupaten Garut serta dampaknya terhadap komitmen organisasi pada lingkungan perguruan tinggi. Selain itu penelitian ini memiliki urgensi untuk mengetahui seberapa besar peranan teknologi informasi ditengah-tengah organisasi yang belum optimal menerapkan Teknologi tersebut sebagai alat pendukung dalam proses bisnis di perguruan tinggi swasta. Metodologi Penelitian yang digunakan adalah Penelitian desrkiptif dan verifikatif. Penelitian deskriptif bertujuan untuk memperoleh gambaran atau karakteristik dari suatu variabel, dalam hal ini variabel teknologi informasi, iklim organisasi perguruan tinggi dan komitmen organisasi perguruan tinggi. Hasil dari penelitian ini mengungkapkan bahwa terdapat pengaruh yang signifikan antara teknologi informasi pada iklim organisasi di perguruan tinggi swasta, selain itu juga terdapat dampak yang signifikan terhap komitmen yang dibangun oleh perguruan tinggi swasta di Kabupaten Garut.
\end{abstract}

Kata Kunci: Teknologi informasi, Iklim organisasi, Komitmen organisasi; Perguruan tinggi swasta. 


\section{PENDAHULUAN}

Teknologi informasi merupakan salah satu entitas yang sangat strategis dalam mempertahankan eksistensi sebuah organisasi (Hamdani and Maulani, 2019). Setiap organisasi memiliki tujuan agar dapat mencapai posisi unggul dalam persaingan, tak terkecuali Perguruan Tinggi Swasta (Maulani and Hamdani, 2019). Mandiri dalam penggunaan Teknologi Informasi pada perguruan tinggi swasta di Indonesia merupakan tuntutan yang harus dipenuhi dalam menghadapi era Revolusi Industri 4.0 dan era Society 5.0 (Maulani and Hamdani, 2018). Oleh karenanya hal tersebut dipandang sebagai strategi bisnis yang dapat menjadi sumber daya dalam meningkatkan kinerja perguruan tinggi swasta.

Tabel 1. Jumlah Perguruan Tinggi Swasta 3 Tahun Terakhir di Indonesia (Kementerian Riset,

\begin{tabular}{lrrr}
\multicolumn{4}{c}{ 2018) } \\
\hline Tahun & $\mathbf{2 0 1 6}$ & $\mathbf{2 0 1 7}$ & $\mathbf{2 0 1 8}$ \\
\hline Jumlah & 3124 & 3154 & 3171 \\
PTS & & & \\
\hline
\end{tabular}

Data dalam 3 tahun terakhir, Indonesia merupakan Negara di Asia Tenggara yang memiliki Perguruan Tinggi terbanyak, saat ini di Indonesia pada Tahun 2018 tercatat terdapat sebanyak 3.171 perguruan tinggi swasta (Kementerian Riset, 2018). Sedangkan pada tahun 2017 Perguruan Tinggi swasta berjumlah 3154 dan pada tahun 2016 berjumlah 3124 (Tinggi, 2016; Kementerian Pendidikan Tinggi, 2017). Dalam 3 tahun terakhir, secara kuantitas jumlah Perguruan Tinggi Swasta di Indonesia mengalami peningkatan, sehingga dapat dikatakan bahwa perguruan tinggi swasta di Indonesia semakin banyak dan semakin ketat dalam persaingan antara satu dengan yang lainnya.

Namun dibalik data tersebut, terdapat fakta yang menunjukkan sebagian besar perguruan tinggi belum maksimal dalam menggunakan teknologi informasi yang terintegrasi dalam setiap proses bisnisnya. Padahal Iklim organisasi memiliki peranan yang vital dalam menciptakan komitmen organisasi dalam mencapai tujuan organisasi tersebut (Permarupan et al., 2013). Dalam perkembangannya iklim organisasi yang dibentuk dari sumber daya yang baik pada perguruan tinggi swasta dapat meningkatkan potensi komitmen organisasi (Berberoglu, 2018).

Pada dasarnya penelitian ini memiliki urgensi yaitu dapat mengetahui seberapa besar peranan teknologi informasi ditengah-tengah organisasi yang belum optimal menerapkan Teknologi tersebut sebagai alat pendukung dalam proses bisnis di perguruan tinggi swasta. sehingga pihak manajemen atau pimpinan perguruan tinggi dapat membuat kebijakan yang relevan, efektif dan efisien

Mengingat fenomena serta potensi yang dikaji pada penelitian ini, maka penelitian penting untuk dilakukan dalam rangka meningkatkan keunggulan bersaing perguruan tinggi yang dampaknya akan meningkatkan kualitas pendidikan di Indonesia.

\section{KAJIAN PUSTAKA}

\subsection{Konsep Teknologi Informasi}

Penelitian sebelumnya mengungkapkan bahwa, teknologi informasi merupakan salah satu strategi bisnis yang memiliki pengaruh terhadap daya saing organisasi(Laudon and Laudon, 2014). Selain itu, teknologi informasi memiliki dampak yang luar biasa terhadap daya saing perusahaan (Wijnhoven and Wassenaar, 1990). Teknologi informasi pula dapat mempengaruhi sebuah iklim organisasi yang memberikan dampak terhadap daya saing (Akbar, Abbaspour and 
Abachian, 2013). Beberapa Hasil penelitian menunjukkan bahwa penggunaan Teknologi Informasi relevan dalam meningkatkan kinerja inovasi perusahaan dalam menciptakan daya saing (Ismaeel et al., 2016a). Banyak penelitian sebelumnya yang telah dilakukan melaporkan temuan yang sama. Penelitian lainnya menemukan bahwa ada interaksi antara kemampuan teknologi informasi dan sumber daya manusia dapat mempengaruhi kemampuan Teknologi Informasi untuk secara efektif meningkatkan daya saing sebuah organisasi(Chen and Tsou, 2012). (Akbar, Abbaspour and Abachian, 2013) Teknologi informasi dapat dikategorikan menjadi tiga indikator, antara lain : Teknologi Informasi sebagai keunggulan kompetitif, keyakinan yang kuat dalam Teknologi Informasi tingkat lanjut, Teknologi Informasi untuk mengakomodasi kebutuhan pelanggan. Selain itu ada pula yang mendefinisikan kemampuan Teknolofi Informasi yang dibangun di atas empat sumber daya: infrastruktur TI, pengalaman bisnis TI, sumber daya hubungan TI, dan sumber daya manusia TI (Chen and Tsou, 2012).

Teknologi Informasi merupakan salah satu alat yang penting dalam kegiatan layanan organisasi bisnis dalam sebuah perusahaan (Ismaeel et al., 2016b). Selain itu, teknologi informasi merupakan sumber daya strategis yang penting bagi organisasi, termasuk perguruan tinggi. Hal tersebut memberikan kontribusi yang sangat positif terhadap informasi yang berdampak pada pengambilan keputusan (Mitić et al., 2017). Dalam mengukur atau menganalisis Teknologi Informasi dapat menggunakan beberapa indikasi antara lain Kualitas Informasi, Kualitas Sistem dan Kualitas pelayanan (Abrego Almazán, Sánchez Tovar and Medina Quintero, 2017).

\subsection{Konsep Iklim Organisasi}

Iklim organisasi sebenarnya adalah seperangkat sifat yang menggambarkan suatu organisasi. Ini berbeda organisasi dari organisasi lain dan tetap untuk jangka waktu tertentu. Ini juga memengaruhi perilaku kerja karyawan di organisasi tertentu. Iklim organisasi adalah sebuah fenomena yang dialami para peneliti dalam praktik lapangan yang timbul dari kondisi organisasi yang berbeda-beda (West, 2015). Iklim organisasi memiliki pengaruh positif terhadap keberlangsungan daya saing sebuah organisasi (Sarros, Cooper and Santora, 2008), hal tersebut didukung oleh penelitian lainnya (Ceyda and Sevinc, 2012; Permarupan et al., 2013). Terdapat beberapa dimensi dari iklim organisasi, antara lain : clarity, standards, Responsibility, Flexibility, Rewards, Team Commitment (Nair, 2006; Waspodo and Minadaniati, 2012). Iklim organisasi yang sehat merupakan proposisi jangka panjang. Setiap Manajer perlu mengambil pendekatan aset terhadap iklim, yang berarti bahwa mereka mengambil pandangan jangka panjang dari iklim sebagai aset organisasi (Haritha and Subrahmanyam, 2013).

Mengkaji tentang dimensi-dimensi iklim organisasi dalam suatu model alat ukur yang disebut Litwin \& Stringer' Organizational Climate (LSOC) (Waspodo and Minadaniati, 2012). Berikut ini adalah 6 (enam) dimensi iklim organisasi sebagai berikut (Nair, 2006; Waspodo and Minadaniati, 2012):

1. Flexibility conformity. merupakan kondisi organisasi yang untuk memberikan keleluasan bertindak bagi karyawan serta melakukan peyesuaian diri terhadap tugas-tugas yang diberikan.

2. Responsibility. Hal ini berkaitan dengan perasaan karyawan pelaksanaan tugas organisasi yang diemban, karena mereka terlibat di dalam proses yang sedang berjalan.

3. Standards. Perasaan karyawan tentang kondisi organisasi dimana manajemen memberikan perhatian kepada pelaksanaan tugas dengan baik, tujuan yang telah ditentukan. 
4. Reward. Hal ini berkaitan dengan perasaan karyawaan tentang penghargaan dan pengakuan atas kerja baik.

5. Clarity. Terkait dengan perasaan pegawai bahwa mereka mengetahui apa yang diharapkan dari mereka dengan pekerjaan, peranan dan tujuan organisasi.

6. Tema Commitment. Berkaitan dengan perasaan karyawan mengenai perasaan bangga mereka memiliki organisasi dan kesediaan untuk berusaha lebih saat dibutuhkan.

\subsection{Konsep Komitmen Organisasi}

Konsep komitmen organisasi pada dasarnya adalah keterikatan secara psikologis bagi karyawan terdapat organisasi(Cesário and Chambel, 2017). Komitmen organisasi merupakan suatu kekuatan dalam mengidentifikasi individu dengan tujuan organisasi. Komitmen organisasi pula merupakan konstruk yang multidimensi yang terdiri dari tiga komponen yaitu afektif, kontinuitas dan normatif. Komitmen afektif berkaitan dengan keterikatan secara emosional bagi karyawan terdapat keterlibatannya dalam organisasi(Genevičiūtè-Janonienè and Endriulaitiené, 2014). Komitmen kontinuitas berkaitan dengan kesadaran seseorang dengan biaya yang terkait ketika meninggalkan organisasinya saat ini. Sedangkan komitmen normatif adalah Persepsi kewajiban bagi karyawan untuk tetap bersama organisasi (Meyer and Allen, 1991).

Beberapa penelitian sebelumnya menunjukkan bahwa meningkatkan iklim organisasi bisa menjadi strategi yang berharga untuk meningkatkan komitmen organisasi(Bahrami et al., 2016). Selain itu komitmen organisasi terlihat pada arah organisasi yang tertarik untuk memiliki karyawan yang memiliki komitmen tinggi, karena secara komitmen yang tinggi berbanding lurus dengan tingkat turnover karyawan yang lebih rendah, peningkatan motivasi dan dukungan organisasi yang berkelanjutan(Hanaysha, 2016).

Sintesa dari berbagai teori dan hasil penelitian terdahulu menghasilkan struktur landasan teori yang dipergunakan untuk penelitian, yakni sebagai grand Theory nya adalah Manajemen Stratejik, sedangkan untuk middle-range theory adalah Manajemen Sumber Daya Manusia, Sistem Informasi Bisnis. Landasan applied Theory yang dipakai adalah teknologi Informasi, Iklim Organisasi, Komitmen Organisasi. Struktur landasan teori penelitian ini diperjelas pada Tabel 2.

Tabel 2. Struktur Landasan Teori untuk Penelitian

\begin{tabular}{|l|l|}
\hline & $\begin{array}{l}\text { Manajemen Stratejik } \\
\text { (Wheelen et al., 2018);(Wheelen and Hunger, 2012);(David, } \\
\text { 2011), (Stacey, 2011),(Thompson and Martin, 2005; Huang and } \\
\text { Lee, 2012) }\end{array}$ \\
\hline & $\begin{array}{l}\text { Manajemen Sumber Daya Manusia } \\
\text { (Sokol } \text { et al., 2015),(Mathis and Jackson, 2008) }\end{array}$ \\
\cline { 2 - 2 } & $\begin{array}{l}\text { Sistem Informasi Bisnis } \\
\text { (Iranmanesh } \text { et al., 2012),(Laudon and Laudon, 2014) }\end{array}$ \\
\hline & $\begin{array}{l}\text { Teknologi Informasi } \\
\text { (Sarvi and Pillay, 2015),(Naqvi and Bashir, 2015),(S Pant, 1995; } \\
\text { Gusaptono, Effendi and Charibaldi, 2012) }\end{array}$ \\
\cline { 2 - 2 } & $\begin{array}{l}\text { Iklim Organisasi } \\
\text { (Arya and Sainy, no date; Wahiza, Wahat and D, no date; Gül, } \\
\text { 2008; Raza, 2010; Reyes and Zapata, 2014; Sokol et al., 2015; } \\
\text { Apipalakul and Kummoon, 2017) }\end{array}$ \\
\hline
\end{tabular}




\begin{tabular}{|l|l|}
\hline & $\begin{array}{l}\text { Komitmen Organisasi } \\
\text { (Permarupan et al., 2013; Ibrahim and Al Falasi, 2014; Bahrami } \\
\text { et al., 2016; Hanaysha, 2016; Berberoglu, 2018) }\end{array}$ \\
\hline
\end{tabular}

Sumber : hasil sintesis beberapa literatur

Dengan demikian, setelah menganalis dan mengkaji masing-masing konstruk berupa variabel penelitian dan hubungan antar variabel, maka untuk membangun paradigma penelitian ini, terlebih dahulu akan dikemukakan kerangka pemikian sebagaimana berikut pada gambar:

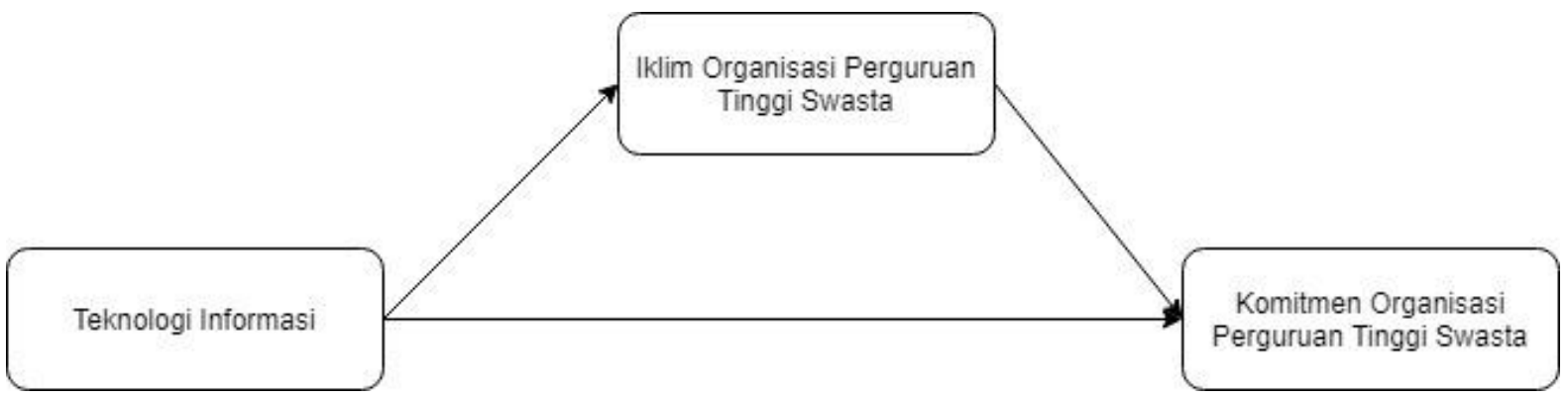

Gambar 1. Paradigma Penelitian

\section{METODE PENELITIAN}

Sesuai dengan tujuan penelitian yang ingin dicapai, maka digunakan dua jenis penelitian yaitu penelitian deskriptif dan penelitian verifikatif. Metode penelitian yang digunakan adalah metode descriptive survey dan explanatory survey dengan unit analisis organisasi, yaitu perguruan tinggi swasta di Jawa Barat khususnya di Kabupaten Garut dan unit observasi adalah pengelola perguruan tinggi swasta yang terdiri atas Pimpinan Perguruan Tinggi, Tenaga Kependidikan dan Tenaga Pendidik.

Data dikumpulkan dalam rentang waktu "one shoot"- cross sectional, yaitu dilakukan dengan data yang hanya sekali dikumpulkan dalam rangka menjawab pertanyaan penelitian. Dalam penelitian ini pengolahan data menggunakan software SEM-PLS.

Penjabaran operasionalisasi dari variabel-variabel yang diteliti dapat dilihat pada Tabel 3.2 di bawah ini:

Tabel 3

Operasionalisasi Variabel

\begin{tabular}{|c|c|c|c|c|}
\hline Konsep & Variabel & Indikator / Dimensi & Skala & No. Item \\
\hline (1) & (2) & (3) & (4) & (5) \\
\hline $\begin{array}{l}\text { Komitmen } \\
\text { Organisasi } \\
\text { keterikatan secara } \\
\text { psikologis bagi } \\
\text { karyawan terdapat } \\
\text { organisasi(Cesário } \\
\text { and Chambel, 2017) }\end{array}$ & $\begin{array}{c}\text { Komitmen } \\
\text { Organisasi } \\
\text { Perguruan Tinggi } \\
\text { Swasta }\end{array}$ & $\begin{array}{l}\text { Affective Commitment } \\
\text { keterikatan secara emosional } \\
\text { bagi karyawan terdapat } \\
\text { keterlibatannya dalam } \\
\text { organisasi } \\
\text { Continuance Commitment } \\
\text { berkaitan dengan kesadaran } \\
\text { seseorang dengan biaya } \\
\text { yang terkait ketika } \\
\text { meninggalkan organisasinya } \\
\text { saat ini }\end{array}$ & Interval & 2 \\
\hline
\end{tabular}


Iklim Organisasi

Iklim organisasi sebenarnya adalah seperangkat sifat yang menggambarkan suatu organisasi. In berbeda organisasi dari organisasi lain dan tetap untuk jangka waktu tertentu.

Teknologi Informasi

$\begin{array}{cl}\text { Iklim Organisasi } & \text { Flexibility conformity } \\ \begin{array}{c}\text { Perguruan Tinggi } \\ \text { Swasta }\end{array} & \text { Responsibility } \\ & \text { Standards } \\ & \text { Reward } \\ & \text { Clarity } \\ & \text { Team Commitment }\end{array}$

Team Commitment
Persepsi kewajiban bagi karyawan untuk tetap bersama organisasi

\begin{tabular}{|c|c|c|c|c|}
\hline \multirow[t]{3}{*}{ Teknologi Informasi } & \multirow{3}{*}{$\begin{array}{c}\text { Teknologi } \\
\text { Informasi } \\
\text { Perguruan Tinggi }\end{array}$} & Kualitas Informasi & Interval & 10 \\
\hline & & Kualitas Sistem & Interval & 11 \\
\hline & & Kualitas pelayanan & Interval & 12 \\
\hline
\end{tabular}

\section{HASIL DAN PEMBAHASAN}

Model penelitian ini terdiri dari tiga variabel laten diantaranya teknologi informasi, iklim organisasi, dan komitmen organisasi. Evaluasi model pengukuran berguna untuk mengevaluasi validitas dan realibilitas suatu konstruk. Uji Validitas dilakukan dengan menghitung validitas konvergen dan validitas diskriminan. Validitas konvergen diketahui melalui loading factor. Indikator dikatakan valid secara konvergen, jika nilai loading factor-nya $[\lambda] \geq 0.5$.

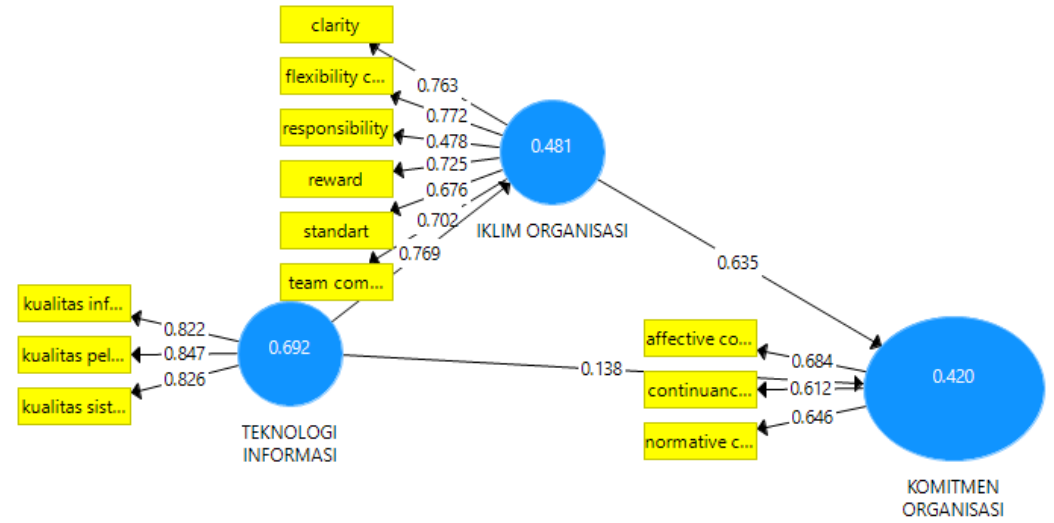

Gambar 2. PLS Algorithm

Berdasarkan output diatas, dapat diketahui bahwa ada salah satu indikator yaitu Responsibility yang mengukur variabel Iklim Organisasi memiliki nilai 0,478<0,5. Ini artinya indikator Responsibility tidak valid, sehingga perlu dipertimbangkan untuk dipertahankan atau dibuang dengan meilhat uji lanjutan lainnya. Untuk menghitung validitas diskriminan dengan cara membandingkan nilai loading factor pada Cross Loading. Suatu indikator dinyatakan valid jika mempunyai loading factor tertinggi sesuai variabel yang didukungnya kemudian 
dibandingkan loading factor kepada variabel lain. Berikut hasil Cross Loading yang disajikan dengan tabel 4 :

Tabel 4. Cross Loading

\begin{tabular}{llccc}
\hline \multirow{2}{*}{ VARIABEL } & \multicolumn{1}{c}{ INDIKATOR } & \multicolumn{3}{c}{ CROSS LOADING } \\
\cline { 3 - 3 } & $\begin{array}{c}\text { KOMITMEN } \\
\text { ORGANISASI }\end{array}$ & $\begin{array}{c}\text { IKLIM } \\
\text { ORGANISASI }\end{array}$ & $\begin{array}{c}\text { TEKNOLOGI } \\
\text { INFORMASI }\end{array}$ \\
\hline KOMITMEN & AFFECTIVE COMMITMENT & $\mathbf{0 , 4 7 5}$ & 0,361 & 0,233 \\
ORGANISASI & CONTINUANCE & $\mathbf{0 , 4 2 5}$ & 0,308 & 0,408 \\
& COMMITMENT & $\mathbf{0 , 4 4 9}$ & 0,33 & 0,201 \\
IKLIM & NORMATIVE COMMITMENT & 0,454 & $\mathbf{0 , 5 3 6}$ & 0,38 \\
ORGANISASI & FLEXIBILITY CONFORMITY & 0,231 & $\mathbf{0 , 3 3 2}$ & 0,203 \\
\cline { 2 - 3 } & RESPONSIBILITY & 0,347 & $\mathbf{0 , 4 6 9}$ & 0,392 \\
& STANDART & 0,415 & $\mathbf{0 , 5 0 3}$ & 0,432 \\
& REWARD & 0,379 & $\mathbf{0 , 5 3 0}$ & 0,402 \\
& CLARITY & 0,258 & $\mathbf{0 , 4 8 8}$ & 0,363 \\
TEKNOLOGI & KUALITAS INFORMASI & 0,369 & 0,454 & $\mathbf{0 , 5 7 1}$ \\
INFORMASI & KUALITAS SISTEM & 0,353 & 0,415 & $\mathbf{0 , 5 7 4}$ \\
& KUALITAS PELAYANAN & 0,362 & 0,461 & $\mathbf{0 , 5 7 4}$ \\
\hline
\end{tabular}

Tabel 4 menunjukkan bahwa loading factor untuk indikator pada masing-masing variabel mempunyai loading factor lebih tinggi dari pada variabel yang lain. Sebagai ilustrasi loading factor 'Affective Commitment' kepada 'Komitmen Organisasi' adalah sebesar 0,475 yang lebih tinggi dari pada loading factor kepada Iklim Organisasi (0,361), dan Teknologi Informasi $(0,233)$. Hal serupa juga tampak pada indikator-indikator yang lain. Dengan demikian, variabel memprediksi indikator pada blok mereka lebih baik dibandingkan dengan indikator di blok yang lain.

Metode lain untuk melihat discriminant validity adalah dengan melihat nilai square root of average variance extracted (AVE). Nilai yang disarankan adalah di atas 0,5 . Berikut adalah nilai AVE dalam penelitian ini:

Tabel 5. Average Variance Extracted

\begin{tabular}{ll}
\hline \multicolumn{1}{c}{ VARIABEL } & AVE \\
\hline KOMITMEN ORGANISASI & 0,420 \\
IKLIM ORGANISASI & 0,481 \\
TEKNOLOGI INFORMASI & 0,692 \\
\hline
\end{tabular}

Berdasarkan tabel 5 terdapat dua variabel yang memiliki nilai AVE $<0,5$. Artinya bahwa ada indikator dari kedua variabel tersebut yang tidak valid. Dengan demikian perlu mempertimbangkan ulang indikator yang digunakan untuk menjelaskan variabel latennya. Uji reliabilitas dilakukan dengan melihat nilai composite reliability dari blok indikator yang mengukur variabel laten. Hasil dikatakan reliabel apabila menunjukkan nilai composite reliability $>0,7$. Berdasarkan hasil analisis menunjukkan bahwa terdapat nilai composite reliability untuk variabel Komitmen Organisasi < 0,7 yang menunjukkan bahwa ada variabel laten pada model yang diestimasi tidak memenuhi kriteria discriminant validity. Nilai composite reliability tersebut sebesar 0,684 pada konstruk Komitmen Organisasi. Sehingga 
perlu dilakukan eliminasi indikator. Kemudian dilakukan eliminasi indikator Responsibility yang berdasar pada hasil dari loading factor yang tidak valid.

Berdasarkan output, nilai loading factor untuk semua indikator sudah valid. Nilai AVE untuk variabel Komitmen Organisasi $(0,419)<0,5$ artinya masih ada variabel yang tidak valid secara diskriminan. Begitu juga dengan nilai composite reliability pada variabel Komitmen Organisasi $<0,7$, yang artinya masih ada variabel belum reliabel. Dilanjutkan untuk eliminasi indikator lainnya. Karena variabel Komitmen Organisasi belum memenuhi standart validitas dan reliabilitas. Maka dilakukan eliminasi lanjut pada variabel Komitmen Organisasi berdasar pada hasil AVE dan Composite Reliability. Kemudian keputusannya adalah mengeliminasi indikator continuance commitment berdasarkan nilai loading factor terkecil pada variabel Komitmen Organisasi yang tersaji pada output model kedua yaitu sebesar 0,629.

Validitas konvergen diketahui melalui loading factor. Indikator dikatakan valid secara konvergen, jika nilai loading factor-nya $[\lambda] \geq 0.5$. Berdasarkan output diatas, dapat diketahui bahwa semua indikator memiliki nilai $>0,5$. Ini artinya semua indikator sudah valid secara konvergen. Disajikan nilai loading factor untuk semua indikator sebagai berikut :

\begin{tabular}{lcc} 
& Tabel 6. Outer Loading & \\
\hline INDIKATOR & LOADING FACTOR & VALIDITAS \\
\hline affective commitment & 0,790 & VALID \\
normative commitment & 0,761 & VALID \\
flexibility conformity & 0,779 & VALID \\
Standart & 0,684 & VALID \\
Reward & 0,736 & VALID \\
Clarity & 0,758 & VALID \\
team commitment & 0,715 & VALID \\
kualitas informasi & 0,828 & VALID \\
kualitas sistem & 0,819 & VALID \\
kualitas pelayanan & 0,847 & VALID
\end{tabular}

Berdasarkan output SMARTPLS bahwa semua variabel memiliki nilai AVE > 0,5. Artinya bahwa semua variabel penelitian sudah valid. Selain itu, semua nilai composite reliability $>0,7$ yang menunjukkan bahwa semua variabel variabel laten pada model yang diestimasi memenuhi kriteria reliabel.

Pada pengujian signifikansi bertujuan untuk mengetahui ada atau tidaknya pengaruh variabel eksogen terhadap intervening dan variabel intervening terhadap variabel endogen maupun pengaruh langsung variabel eksogen terhadap variabel endogen dengan menggunakan path analysis. Uji Signifikansi ini dilakukan dengan menggunakan nilai t-value yang dibandingkan dengan z-score pada CI 95\% = 1.96 Dengan menggunakan nilai dari t statistics dan $\mathrm{p}$ value, apabila nilai $\mathrm{t}$ statistics $>1,96$ dan $\mathrm{p}$ value $<0,05$ maka model signifikan dan sebaliknya. Berikut disajikan output analisis :

Untuk melihat hasil pengujian dirrect effect antara variabel eksogen terhadap variabel endogen tanpa peran variabel mediasi, berikut disajikan dalam tabel :

Tabel 7. Pengujian Direct Effect

\begin{tabular}{|c|l|c|c|c|}
\hline Variabel Eksogen & \multicolumn{1}{|c|}{ Variabel Endogen } & Koefisien Path & T-Statistics & P-Value \\
\hline Teknologi informasi & Iklim organisasi & 0,772 & 17,927 & 0,000 \\
\hline Teknologi informasi & Komitmen organisasi & $-0,154$ & 1,002 & 0,316 \\
\hline
\end{tabular}




\section{Teknologi Informasi terhadap Iklim Organisasi}

Berdasarkan tabel diatas menunjukkan bahwa hubungan antara Teknologi Informasi dan Iklim Organisasi signifikan dengan $t$-statistics $(17,927)>1,96$ dan p-value $(0,000)<0,05$. Koefisien path sebesar 0,772 yang menunjukkan bahwa arah hubungan antara Teknologi Informasi dengan Iklim Organisasi positif. Dengan demikian, semakin meningkatnya Teknologi Informasi maka akan berdampak pada peningkatan kualitas Iklim Organisasi Perguruan Tinggi Swasta di Kabupaten Garut.

\section{Teknologi Informasi terhadap Komitmen Organisasi}

Berdasarkan tabel diatas menunjukkan bahwa hubungan antara Teknologi Informasi dan Komitmen Organisasi tidak signifikan dengan t-statistics $(1,002)<1,96$ dan p-value $(0,316)\rangle$ 0,05. Koefisien path sebesar -0,154 yang menunjukkan bahwa arah hubungan antara Teknologi Informasi dengan Komitmen Organisasi negative. Dengan demikian, perubahan Teknologi Informasi tidak berdampak pada perubahan Komitmen Organisasi Perguruan Tinggi Swasta di Kabupaten Garut.

\section{Iklim Organisasi terhadap Komitmen Organisasi}

Berdasarkan tabel diatas menunjukkan bahwa hubungan antara Iklim Organisasi dan Komitmen Organisasi adalah signifikan dengan t-statistics $(5,967)>1,96$ dan p-value $(0,000)$ $<0,05$. Koefisien path sebesar 0,724 yang menunjukkan bahwa arah hubungan antara Iklim Organisasi dengan Komitmen Organisasi positif. Dengan demikian, semakin meningkatnya Iklim Organisasi maka akan berdampak pada peningkatan kualitas Komitmen Organisasi Perguruan Tinggi Swasta di Kabupaten Garut.

Tabel 8. Pengujian Indirect Effect

\begin{tabular}{cccccc}
\hline $\begin{array}{c}\text { Variabel } \\
\text { Eksogen }\end{array}$ & $\begin{array}{c}\text { Variabel } \\
\text { Endogen }\end{array}$ & $\begin{array}{c}\text { Variabel } \\
\text { Mediasi }\end{array}$ & $\begin{array}{c}\text { Koefisien } \\
\text { Path }\end{array}$ & T-Statistics & P-Value \\
\hline Teknologi & Komitmen & $\begin{array}{c}\text { Iklim } \\
\text { Informasi }\end{array}$ & 0,559 & 5,270 & 0,000 \\
\hline
\end{tabular}

Berdasarkan tabel diatas dijelaskan bahwa pengaruh tidak langsung Teknologi Informasi dengan Komitmen Organisasi yang di mediasi Iklim Organisasi signifikan dengan t-statistics $(5,270)>1,96$ dan p-value $(0,000)<0,05$. Koefisien indirect sebesar 0,559 yang menunjukkan bahwa arah hubungan antara variabelnya positif.

Berdasarkan Koefisien Determinasi $\left(\mathrm{R}^{2}\right)$ menunjukkan bahwa $\mathrm{R}^{2}$ variabel Iklim Organisasi adalah sebesar 0.597 yang berarti 59,7\% Iklim Organisasi dipengaruhi oleh Teknologi Informasi, sedangkan sisanya sekitar 40,3\% dijelaskan oleh variabel lain di luar model penelitian. Nilai $\mathrm{R}^{2}$ variabel Komitmen Organisasi adalah sebesar 0.376 yang berarti $37,6 \%$ Komitmen Organisasi dipengaruhi oleh Teknologi Informasi dan Iklim Organisasi, sedangkan sisanya sekitar 62,4\% dijelaskan oleh variabel lain di luar model penelitian. Berdasarkan Uji Relevansi Prediktif (Q2) menunjukkan bahwa nilai $\mathrm{Q}^{2}$ variabel Iklim Organisasi Information sebesar 0.312 dan variabel Komitmen Organisasi sebesar 0.202. Hal ini berarti bahwa hasil model menunjukkan validitas prediktif yang baik karena nilai $\mathrm{Q}^{2}>0$. 


\section{KESIMPULAN DAN SARAN}

Teknologi Informasi memiliki pengaruh yang sangat signifikan terhadap iklim organisasi pada perguruan tinggi swasta di Kabupaten Garut. Hal terlihat dari beberapa performa yang dapat dikaji dari masing-masing karakteristik perguruan tinggi. Sehingga dapat disimpulkan bahwa semakin meningkatnya Teknologi Informasi maka akan berdampak pada peningkatan kualitas Iklim Organisasi Perguruan Tinggi Swasta di Kabupaten Garut. Namun demikian, perubahan Teknologi Informasi tidak berdampak pada perubahan Komitmen Organisasi Perguruan Tinggi Swasta di Kabupaten Garut. Namun hubungan antara Iklim Organisasi dengan Komitmen Organisasi positif. Dengan demikian, semakin meningkatnya Iklim Organisasi maka akan berdampak pada peningkatan kualitas Komitmen Organisasi Perguruan Tinggi Swasta di Kabupaten Garut. Selain itu, semakin meningkatnya Teknologi Informasi apabila dimediasi oleh Iklim Organisasi maka akan berdampak pada peningkatan Komitmen Organisasi. Dalam penelitian ini mendeteksi adanya mediasi penuh (pengaruh langsung=0), ketika Teknologi Informasi tidak berpengaruh langsung terhadap Komitmen Organisasi. Peran Iklim Organisasi memediasi Teknologi Informasi dan Komitmen Organisasi menjadi berpengaruh positif.

\section{ACKNOWLEDGE}

Ucapan terima kasih kami ucapkan kepada Direktorat Jenderal Pendidikan Tinggi Kementerian Pendidikan dan Kebudayaan Republik Indonesia yang telah mendanai penelitian ini dalam skema hibah penelitian dosen pemula. Selain itu kami ucapkan terima kasih kepada seluruh mitra penelitian yang terlibat.

\section{VII.DAFTAR PUSTAKA}

[1] Abrego Almazán, D., Sánchez Tovar, Y. and Medina Quintero, J. M. (2017) 'Influence of information systems on organizational results', Contaduría $y$ Administración. Universidad Nacional Autónoma de México, Facultad de Contaduría y Administración, 62(2), pp. 321-338. doi: 10.1016/j.cya.2017.03.001.

[2] Akbar, A., Abbaspour, A. and Abachian, R. (2013) 'The Effect of Information Technology on Organizational Structure and Firm Performance: An Analysis of Consultant Engineers Firms ( CEF ) in Iran', Procedia - Social and Behavioral Sciences. Elsevier B.V., 81(2005), pp. 644-649. doi: 10.1016/j.sbspro.2013.06.490.

[3] Apipalakul, C. and Kummoon, D. (2017) 'The Effects of Organizational Climate to Conflict Management amongst Organizational Health Personnel', Procedia - Social and Behavioral Sciences. The Author(s), 237(June 2016), pp. 1216-1222. doi: 10.1016/j.sbspro.2017.02.192.

[4] Arya, M. R. and Sainy, M. (no date) 'To Study the Impact of Organizational Climate on Employee Engagement in the Banking Sector with Special Reference to State Bank of India , Indore'.

[5] Bahrami, M. A. et al. (2016) 'Role of Organizational Climate in Organizational Commitment: The Case of Teaching Hospitals', Osong Public Health and Research Perspectives. Elsevier Korea LLC, 7(2), pp. 96-100. doi: 
10.1016/j.phrp.2015.11.009.

[6] Berberoglu, A. (2018) 'Impact of organizational climate on organizational commitment and perceived organizational performance: Empirical evidence from public hospitals', BMC Health Services Research. BMC Health Services Research, 18(1), pp. 1-9. doi: 10.1186/s12913-018-3149-z.

[7] Cesário, F. and Chambel, M. J. (2017) 'Linking Organizational Commitment and Work Engagement to Employee Performance', Knowledge and Process Management, 24(2), pp. 152-158. doi: 10.1002/kpm.1542.

[8] Ceyda, G. and Sevinc, P. (2012) 'Determination of High Schools Organizational Climate', Procedia - Social and Behavioral Sciences, 46, pp. 2947-2950. doi: 10.1016/j.sbspro.2012.05.595.

[9] Chen, J. and Tsou, H. (2012) 'Journal of Engineering and Performance effects of IT capability, service process innovation, and the mediating role of customer service', Journal of Engineering and Technology Management. Elsevier B.V., 29(1), pp. 7194. doi: 10.1016/j.jengtecman.2011.09.007.

[10] David, F. R. (2011) Strategic Management: Concept and Cases. 13th ed. New Jersey: Prentice Hall.

[11] Genevičiūtè-Janonienè, G. and Endriulaitienè, A. (2014) 'Employees' Organizational Commitment: Its Negative Aspects for Organizations', Procedia Social and Behavioral Sciences, 140, pp. 558-564. doi: 10.1016/j.sbspro.2014.04.470.

[12] Gül, H. (2008) 'Organizational Climate and Academic Staff' s Perception on Climate Factors', Humanity \& social sciences journal, 3(1), pp. 37-48.

[13] Gusaptono, R. H., Effendi, M. I. and Charibaldi, N. (2012) 'The Information Technology (IT) Adoption Process and E- Readiness to Use within Yogyakarta Indonesian Small Medium Enterprises (SME)', JICT-International Journal of Information and Communication Technology Research, 2(1), pp. 29-37.

[14] Hamdani, N. A. and Maulani, G. A. F. (2019) 'The Influence Information Technology Capabilities and Differentiation on the Competitiveness of Online Culinary SMEs', International Journal of Recent Technology and Engineering (IJRTE), 8(1S), pp. 146-150.

[15] Hanaysha, J. (2016) 'Testing the Effects of Employee Engagement, Work Environment, and Organizational Learning on Organizational Commitment', Procedia - Social and Behavioral Sciences. The Author(s), 229, pp. 289-297. doi: 10.1016/j.sbspro.2016.07.139.

[16] Haritha, K. and Subrahmanyam, S. E. V (2013) 'Organisational Climate: An Empirical Investigation in PennaCement Industries Limited ( PCIL )', International Journal of Business and Management Invention, 2(12), pp. 12-20. Available at: www.ijbmi.org.

[17] Huang, H.-I. and Lee, C.-F. (2012) 'Strategic management for competitive advantage: a case study of higher technical and vocational education in Taiwan', Journal of Higher Education Policy and Management, 34(6), pp. 611-628. doi: 10.1080/1360080X.2012.727635.

[18] Ibrahim, M. and Al Falasi, S. (2014) 'Employee loyalty and engagement in uae public sector', Employee Relations, 36(5), pp. 562-582. doi: 10.1108/ER-07-20130098.

[19] Iranmanesh, Fariborz et al. (2012) 'Business information systems', Advances in 
Environmental Biology, 6(5), pp. 1809-1811. doi: 10.1007/978-3-030-20485-3.

[20] Ismaeel, N. et al. (2016a) 'Impact of Information Technology Infrastructure on Innovation Performance: An Empirical Study on private Universities In Iraq', Procedia Economics and Finance. Elsevier B.V., 39(November 2015), pp. 861-869. doi: 10.1016/S2212-5671(16)30250-7.

[21] Ismaeel, N. et al. (2016b) 'Impact of Information Technology Infrastructure on Innovation Performance: An Empirical Study on private Universities In Iraq'. Elsevier B.V., 39(November 2015), pp. 861-869. doi: 10.1016/S22125671(16)30250-7.

[22] Kementerian Pendidikan Tinggi (2017) Statistik Pendidikan Tinggi 2017. Jakarta: Pusat Data dan Informasi Iptek Dikti.

[23] Kementerian Riset, T. dan P. T. (2018) Statistik Pendidikan Tinggi 2018, Kementerian Riset, Teknologi dan Pendidikan Tinggi. Jakarta: Pusat Data dan Informasi Ilmu Pengetahuan, Teknologi, dan Pendidikan Tinggi. Available at: https://ristekdikti.go.id/epustaka/buku-statistik-pendidikan-tinggi-2017/.

[24] Laudon, K. C. and Laudon, J. P. (2014) Management Information Systems THIRTEENTH EDITION GLOBAL EDITION. Global Edi. Edited by Wall Stephanie. Edinburgh: Pearson Education Limited. Available at: www.pearson.com/uk.

[25] Mathis, R. L. and Jackson, J. H. (2008) Human Resource Management Twelfth Edition. Twelfth Ed. OH: Thomson South-Western.

[26] Maulani, G. A. F. and Hamdani, N. A. (2018) 'Perencanaan Strategis Sistem Informasi pada Perguruan Tinggi Swasta di Indonesia ( Studi Kasus pada Institut Pendidikan Indonesia Garut )', Jurnal PETIK, 4(September), pp. 162-166. doi: https://doi.org/10.31980/jpetik.v4i2.367.

[27] Maulani, G. A. F. and Hamdani, N. A. (2019) 'The Influence of Information Technology and Organizational Climate on the Competitiveness of Private Universities in Indonesia', International Journal of Recent Technology and Engineering, 8(1S), pp. 142-145. Available at: https://www.ijrte.org/download/volume-8-issue-1s/.

[28] Meyer, J. P. and Allen, N. J. (1991) 'A THREE-COMPONENT CONCEPTUALIZATION OF ORGANIZATIONAL COMMITMENT', Human Resource Management Review, 1(1), pp. 61-89. doi: 10.1016/1053-4822(91)90011$\mathrm{Z}$.

[29] Mitić, S. et al. (2017) 'The impact of information technologies on communication satisfaction and organizational learning in companies in Serbia', Computers in Human Behavior, 76, pp. 87-101. doi: 10.1016/j.chb.2017.07.012.

[30] Nair, R. (2006) 'Climate studies and associated best practices to improve climate issues in the workplace', in WEPAN-Women in Engineering Programs and Advocates Network. Proceedings of the 2006 WEPAN Conference, pp. 1-8.

[31] Naqvi, S. M. M. R. and Bashir, S. (2015) 'IT-expert retention through organizational commitment: A study of public sector information technology professionals in Pakistan', Applied Computing and Informatics. King Saud University, 11(1), pp. 6075. doi: 10.1016/j.aci.2011.11.001.

[32] Permarupan, P. Y. et al. (2013) 'The Impact of Organizational Climate on Employee ' s Work Passion and Organizational Commitment', Procedia - Social and Behavioral Sciences. Elsevier B.V., 107, pp. 88-95. doi: 
10.1016/j.sbspro.2013.12.403.

[33] Raza, S. A. (2010) 'Impact of organizational climate on performance of college teachers in Punjab', Journal of college teaching \& learning, 7(10), pp. 47-52.

[34] Reyes, M. M. V. and Zapata, D. I. C. (2014) 'Relation between organizational climate and its dimensions and knowledge-sharing behavior among knowledge workers', International Journal of Psychological Research, 7(2), pp. 64-75.

[35] S Pant, C. H. (1995) 'Strategic Information Systems Planning: A Review', Information Resources Management Association International Conference, 6(January), pp. 11-17.

[36] Sarros, J. C., Cooper, B. K. and Santora, J. C. (2008) 'Through Transformational Leadership and Organizational Culture', Journal of Leadership \& Organizational Studies, 15(2), pp. 145-158. doi: 10.1177/1548051808324100.

[37] Sarvi, J. and Pillay, H. (2015) Integrated information and communication technology strategies for competitive higher education in Asia and the Pacific. Asian Development Bank. Available at: https://www.adb.org/sites/default/files/publication/177730/ict-strategies-highereducation.pdf.

[38] Sokol, A. et al. (2015) 'Organizational Climate of Higher Education Institutions and its Implications for the Development of Creativity', Procedia - Social and Behavioral Sciences. Elsevier B.V., 182, pp. 279-288. doi: 10.1016/j.sbspro.2015.04.767.

[39] Stacey, R. D. (2011) Strategic management and organisational dynamics. Sixth Edit. Edinburgh: Pearson Education Limited.

[40] Thompson, J. and Martin, F. (2005) Strategic Management: Awareness and Change. THOMSON.

[41] Tinggi, K. R. T. dan P. (2016) Statistik Pendidikan Tinggi 2014/2015. Jakarta. Available at: http://www.ristekdikti.go.id/wp-content/uploads/2016/11/E-BookStatistik-Pendidikan-Tinggi-2014-2015-revisi.pdf.

[42] Wahiza, N., Wahat, A. and D, P. (no date) 'Organizational Climate as a Predictor to Job Satisfaction of New Faculties in Three Public Universities of Malaysia'.

[43] Waspodo, A. A. and Minadaniati, L. (2012) 'Pengaruh Kepuasan Kerja Dan Iklim Organisasi Terhadap Organizational Citizenship Behavior ( Ocb ) Karyawan Pada PT. Trubus Swadaya', Jurnal Riset Manajemen Sains Indonesia, 3(1), pp. 1-16.

[44] West, M. A. (2015) 'Organizational Climate', International Encyclopedia of Social \& Behavioral Sciences. Second Edi. Elsevier, 16, pp. 322-326. doi: 10.1016/B9780-08-097086-8.73073-X.

[45] Wheelen, T. L. et al. (2018) Strategic Management and Business Policy: Globalization, Innovation and Sustainability.

[46] Wheelen, T. L. and Hunger, J. D. (2012) Strategic management and business policy, Policy. doi: 10.1017/CBO9781107415324.004.

[47] Wijnhoven, A. B. J. M. and Wassenaar, D. A. (1990) 'Impact of Information Technology on Organizations: The State of the Art', International Jurnal of Information Management, 10, pp. 35-53. 